\title{
Faktor-Faktor yang Mempengaruhi Permintaan Jasa Pariwisata Pemandian Air Panas
}

\author{
Rahyuniati Setiawan \\ Fakultas Ekonomi, Universitas Garut \\ Jalan Jati 42 B Garut, 44151, Indonesia \\ rahyu@uniga.ac.id
}

\begin{abstract}
Abstrak- Tujuan dari penelitian ini adalah untuk mengetahui pengaruh harga/tarif masuk, pendapatan konsumen, fasilitas wisata dan selera konsumen, terhadap permintaan jasa pariwisata pemandian air panas se-Kabupaten Garut. Dalam penelitian ini yang menjadi subjek penelitian yaitu konsumen (pengunjung) di pemandian air panas se-Kabupaten Garut. Metode yang digunakan dalam penelitian ini adalah eksplanatory survey. Adapun teknik sampling yang digunakan dalam penelitian ini yaitu systematic sampling. Penelitian ini menggunakan angket sebagai alat pengumpul data dan teknik analisis data menggunakan analisis linier berganda. Hasil penelitian menunjukan bahwa pendapatan konsumen, persepsi fasilitas wisata dan selera konsumen mempunyai pengaruh positif terhadap permintaan jasa pariwisata pemandian air panas, sedangkan persepsi harga tarif masuk mempunyai pengaruh negatif terhadap permintaan jasa pariwisata pemandian air panas.
\end{abstract}

Kata Kunci- permintaan jasa pariwisata, harga/tarif masuk, pendapatan konsumen, fasilitas wisata, selera konsumen

\section{PENDAHULUAN}

Pariwisata di Indonesia pada saat ini mulai berkembang menjadi satu industri di bidang jasa yang berusaha untuk menarik dan memberikan pelayanan untuk memuaskan wisatawan. Pariwisata pun menjadi perangkat penting dalam pembangunan karena disamping dapat menciptakan lapangan kerja dan pendapatan masyarakat, daerah dan negara juga dapat turut memperkenalkan seni budaya, serta keindahan alam Indonesia kepada wisatawan yang mengunjunginnya [1]. Indonesia merupakan negara kepulauan yang terdiri dari 33 provinsi salah satunya adalah Provinsi Jawa Barat.

Provinsi Jawa Barat merupakan salah satu provinsi di Indonesia yang memiliki wisata alam yang melimpah. Selain itu Jawa Barat merupakan provinsi yang paling dekat dengan Ibu Kota Negara, yang sedikitnya bisa berdampak positif dalam pengembangan pariwisatanya, karena kemudahan transportasi dan jarak tempuh dari ibu kota negara. Di Jawa Barat terdapat berbagai macam objek wisata dengan berbagai daya tarik tersendiri seperti pegunungan, pantai, marga satwa dan lain sebagainya. Kota Bandung yang merupakan ibu kota dari Provinsi Jawa Barat memiliki kekayaan alam yang bisa menarik wisatawan dengan menyajikan berbagai jenis tempat pariwisata diantaranya: Kebun Binatang, Gunung Tangkuban Perahu, Kawah Putih, taman bunga dan pemandian Air Panas Ciater.

Sejak pemerintah mengeluarkan kebijakan otonomi daerah pada tahun 2000 yang mana setiap daerah otonom diwajibkan untuk mengatur dan mengelola sendiri potensi- potensi yang ada didaerahnya masing-masing tanpa campur tangan pemerintah pusat. Meskipun dalam pelaksanaannya kebijakan otonomi daerah ini tidak secara serentak dapat menghasilkan perubahan yang menguntungkan karena banyak hal yang harus dipersiapkan dan dibenahi oleh masing- masing daerah dalam rangka menggali potensi- potensi yang dimiliki untuk dimanfaatkan guna pengembangan kegiatan pembangunan.

Salah satu kabupaten yang dekat dengan Ibu Kota Provinsi Jawa Barat ini adalah Garut. Panorama yang sangat indah dimiliki oleh kabupaten ini, sehingga pernah dijuluki Swiss van java oleh Charlie Chaplin pada dua kali kunjungannya pada tahun 1927 dan 1933. Julukan tersebut membuktikan bahwa Garut memang dapat menjadi salah satu potensi pariwisata, meskipun masih kurangnya fasilitas yang dimiliki kabupaten ini namun. Sebagaimana dikemukakan 
oleh Yetie Rohayati (DISBUDPAR, 2011:5) bahwa "Garut belum menjadi daerah tujuan wisata dengan fasilitas lengkap, namun kami terus berbenah dan membangun untuk memuaskan kunjungan anda."Dari ungkapan tersebut dapat disimpulkan bahwa kabupaten Garut memiliki potensi pariwisata dengan kekayaan alam yang indah namun masih dalam proses pengembangan dari segi fasilitasnya.

Tempat wisata di Kabupaten Garut banyak namun jarak dari satu wisata ke wisata lainnya cukup jauh dan terdapat kekurangan yaitu dalam segi akomodasi selain jarangnya angkutan umum jalannya pun tidak sebagus jalan provinsi. Oleh sebab itu melihat waktu dan biaya penulis memilih menelti sebagian kecil dari pariwisata di kabupaten Garut yaitu menyoroti bagian objek wisata air panas, tidak semua wisata air panas dikelola oleh PEMDA, dengan kata lain banyak pihak swasta yang ikut andil dalam pengelolaan objek wisata ini.

Dalam perkembangannya sektor wisata di kawasan kabupaten Garut setiap tahunnya terus mengalami fluktuasi sampai pada tahun 2011, hal tersebut terlihat dari tingkat kunjungan wisatawan pada sejumlah objek wisata air panas di kawasan Kabupaten Garut yang terus mengalami naik turun, baik itu dari wisatawan domestik maupun wisatawan mancanegara. Berikut ini disajikan pertumbuhan tingkat kunjungan wisatawan pada objek wisata air panas se Kabupaten Garut.

Tabel 1.2

Jumlah Kunjungan Wisatawan pada Objek Wisata Air Panas

Se Kabupaten Garut

\begin{tabular}{lccc}
\hline \multicolumn{1}{c}{ Objek Wisata } & \multicolumn{2}{c}{$\begin{array}{c}\text { Jumlah Pengunjung } \\
\text { (orang) }\end{array}$} & $\begin{array}{c}\text { Laju } \\
\text { Pertumbuhan } \\
(\mathbf{\%})\end{array}$ \\
\cline { 2 - 3 } & \multicolumn{2}{c}{$\mathbf{2 0 1 0}$} & $\mathbf{2 0 1 1}$ \\
\hline Antralina & 6732 & 5312 & $-21,09$ \\
Aquarius & 5032 & 3972 & $-25,03$ \\
Cipanas Indah & 7704 & 6076 & $-21,13$ \\
Danau Dariza & 9620 & 12344 & 28,31 \\
Darajat Pass & 3452 & 2096 & $-39,28$ \\
Lembur Kuring & 2260 & 4940 & 118,58 \\
Sabda Alam & 10036 & 7816 & $-22,12$ \\
Sumber Alam & 14920 & 11624 & $-22,09$ \\
Surya Alam & 5432 & 3980 & $-26,73$ \\
Tirtagangga & 11308 & 8800 & $-22,17$ \\
\hline
\end{tabular}

\begin{tabular}{cccc}
\hline JUMLAH & 79220 & 64236 & $-18,91$ \\
\hline
\end{tabular}

Sumber : Dinas Kebudayaan dan Pariwisata dan Rekapitulasi Tahunan per Objek Wisata

Berdasarkan pada tabel 1.2 dapat diketahui bahwa terjadi penurunan permintaan pada beberapa objek wisata pemandian air panas se Kabupaten Garut pada rentang tahun 2010-2011 hal tersebut terlihat pada jumlah kunjungan wisatawan pada beberapa objek wisata air panas se Kabupaten Garut yang mengalami penurunan jumlah kunjungan meskipun pada beberapa objek wisata air panas ada yang mengalami peningkatan jumlah kunjungan pada rentang tahun yang sama seperti objek wisata air panas Danau Dariza yang pada tahun 2011 jumlah pengunjungnya sebesar 9.620 orang meningkat sebanyak $28,31 \%$ pada tahun 2010, selain itu keadaan yang sama pada objek wisata air panas Lembur Kuring mengalami peningkatan sebanyak 118,58\% pada tahun 2011 . Dari beberapa objek wisata air panas se Kabupaten Garut yang mengalami peningkatan, ada beberapa objek wisata air panas yang mengalami penurunan diantaranya wisata air panas Antralina yang terus mengalami penurunan pengunjung selama tahun 2010-2011 yakni mengalami penurunan sebanyak $21,09 \%$ keadaan serupa ditunjukan pada objek wisata air panas Aquarius yang pada tahun 2010 dengan jumlah pengunjung sebanyak 5.032 orang menurun pada tahun 2011 sebanyak 3.972 orang selain itu objek wisata air panas Cipanas Indah pun mengalami penurunan sebanyak 21,13\% diikuti dengan wisata air panas Darajat Pass. Hal serupa masih terjadi pada beberapa objek wisata seperti objek wisata air panas Sabda Alam, Sumber Alam, Surya Alam dan Tirta Gangga yang terus menurun sampai pada tahun 2011. Sehingga dari uraian diatas dapat disimpulkan bahwa selama rentang tahun 2010 sampai pada tahun 2011 jumlah kunjungan wisatawan pada objek wisata air panas se-Kabupaten Garut mengalami penurunan sebanyak $18,91 \%$ yaitu dari 79.220 pada tahun 2010 menjadi 64.236 orang pada tahun 2011.

Berdasarkan data di atas dan melihat terjadinya penurunan kunjungan terhadap sejumlah objek wisata air panas di Kabupaten Garut, penulis tertarik untuk meneliti mengapa 
terjadi penurunan kunjungan pada wisata air panas di Kabupaten Garut tersebut.

Penurunan- penurunan tersebut diduga disebabkan terdapatnya wisata alam sejenis di setiap kabupaten atau kota yang jaraknya berdekatan dengan kabupaten garut seperti wisata alam Galunggung yang terdapat di Kota Tasikmalaya dan ciater yang terdapat di Kabupaten Bandung, selain itu gaya hidup masyarakat telah dimanjakan oleh teknologi canggih seperti banyaknya penduduk yang memiliki alat pemanas air di tempat tinggalnya sehingga tidak perlu pergi ke pemandian air panas lagi. Pentingnya penelitian ini dapat sedikitnya mengetahui penyebab mengapa terjadinya penurunan jumlah pengunjung dan dan membantu pemerintah Kabupaten Garut juga pihak swasta pengelola objek wisata pemandian air panas untuk dapat mengetahui kekurangan-kekurangan dari objek wisatanya.

Tujuan dari penelitian ini adalah untuk mengetahui faktor-faktor yang mempengaruhi permintaan jasa pariwisata pemandian air panas se Kabupaten Garut. Untuk mengetahui gambaran persepsi harga tiket masuk, pendapatan konsumen, persepsi fasilitas wisata, selera dan permintaan jasa pariwisata di objek wisata air panas se Kabupaten Garut

Hipotesis dalam penelitian ini adalah persepsi harga/tarif objek wisata berpengaruh negatif terhadap permintaan jasa pariwisata, pendapatan konsumen berpengaruh positif terhadap permintaan jasa pariwisata, persepsi fasilitas wisata berpengaruh positif terhadap permintaan jasa pariwisata dan selera konsumen berpengaruh positif terhadap permintaan jasa pariwisata.

\section{METODOLOGI PENELITIAN}

Metode penelitian yang digunakan dalam penelitian ini adalah metode penelitian survey. Kerlinger (Sugiyono, 2008:7) mengemukakan bahwa :

Metode penelitian survey adalah penelitian yang dilakukan pada populasi besar maupun kecil tetapi data yang dipelajari adalah data dari sample yang diambil dari populasi tersebut sehingga ditentukan kejadian- kejadian relative, distribusi, dan hubungan- hubungan antar variabel sosiologis maupun psikologis. Selain itu juga digunakan metode eksplanatory atau penjelasan yaitu suatu metode menyoroti adanya hubungan antar variabel dengan menggunakan kerangka kemudian dirumuskan suatu hipotesis.

Untuk mengetahui apakah semua variabel penjelas yang di gunakan dalam model regresi secara serentak atau bersama-sama berpengaruh terhadap variabel yang dijelaskan, digunakan uji statistik F, hipotesis yang digunakan adalah :

Ho : $\alpha 1, \alpha 2, \alpha 3=0$ semua variabel independen tidak mempengaruhi variabel dependen secara bersama-sama

$\mathrm{H} 1: \alpha 1, \alpha 2, \alpha 3 \neq 0 \quad$ semua variabel independen mempengaruhi variabel dependen secara bersama-sama

Nilai F hitung dicari dengan rumus:

(Yana Rohmana, 2010:80)

$$
F=\frac{\mathrm{R}^{2} /(\mathrm{k}-\mathrm{l})}{\left(I-R^{2}\right) I(N-k)}
$$

Dimana:

$\mathrm{R} 2$ = Koefisien determinasi

$\mathrm{N}=$ Jumlah observasi

$\mathrm{k}=$ Jumlah variabel

Pada tingkat signifikansi 5 persen dengan kriteria pengujian yang digunakan sebagai berikut:

1. H0 diterima dan $\mathrm{H} 1$ ditolak apabila F hitung < F tabel, atau jika probabilitas Fhitung > tingkat signifikansi 0,05 maka H0 ditolak, artinya variabel penjelas secara serentak atau bersama-sama tidak mempengaruhi variabel yang dijelaskan secara signifikan.

2. H0 ditolak dan $\mathrm{H} 1$ diterima apabila $\mathrm{F}$ hitung $>$ F tabel, atau jika probabilitas Fhitung < tingkat signifikansi 0,05 maka H0 ditolak, artinya variabel penjelas secara serentak atau bersama-sama mempengaruhi variabel yang dijelaskan secara signifikan.

Untuk menghitung nilai $\mathrm{t}$ hitung digunakan rumus:

$$
t=\frac{\beta \mathrm{i}}{\operatorname{Se}(\beta \mathrm{i})}
$$

(Yana Rohmana, 2010:74) 
Pengujian ini dilakukan untuk melihat adanya pengaruh dari masingmasing variabel penjelas terhadap variabel yang dijelaskan. Mulamula ditentukan hipotesis nol atau null hypotesis (Ho) yang menyatakan bahwa masing-masing variabel penjelas berpengaruh terhadap variabel yang dijelaskan secara individu.

Hipotesis yang diuji pada uji statistik t adalah sebagai berikut :

a. Hipotesis untuk X1

$\mathrm{H} 0: \beta 1=0$ tidak ada pengaruh antara Harga

(X1) terhadap permintaan jasa pariwisata(Y).

$\mathrm{H} 1: \beta 1<0$ ada pengaruh negatif antara Harga

(X1) terhadap permintaan jasa pariwisata (Y).

b. Hipotesis untuk X2

$\mathrm{H} 0: \beta 2=0$ tidak ada pengaruh antara

Pendapatan Konsumen (X2) terhadap permintaan jasa pariwisata (Y).

$\mathrm{H} 1: \beta 2>0$ ada pengaruh positif antara

Pendapatan Konsumen (X2) terhadap permintaan jasa pariwisata (Y).

c. Hipotesis untuk X3

$\mathrm{HO}: \beta 3=0$ tidak ada pengaruh antara

Fasilitas (X3) terhadap permintaan jasa pariwisata $(\mathrm{Y})$.

$\mathrm{H} 1: \beta 3>0$ ada pengaruh positif antara

Fasilitas (X3) terhadap permintaan jasa pariwisata $(\mathrm{Y})$.

d. Hipotesis untuk X4

$\mathrm{H} 0: \beta 4=0$ tidak ada pengaruh antara Selera

(X4) terhadap permintaan jasa pariwisata (Y).

$\mathrm{H} 1: \beta 4>0$ ada pengaruh positif antara Selera

(X4) terhadap permintaan jasa pariwisata (Y).

Pada tingkat signifikasi 5 persen dengan pengujian yang digunakan adalah sebagai berikut

- Ho diterima dan H1 ditolak apabila t hitung $<\mathrm{t}$ tabel atau jika probabilitas $\mathrm{t}$ hitung > tingkat signifikansi 0,05, artinya adalah salah satu variabel independen tidak mempengaruhi variabel dependen secara signifikan.
- Ho ditolak dan H1 diterima apabila $t$ hitung > t tabel, atau jika probabilitas thitung < tingkat signifikansi 0,05, artinya adalah salah satu variabel independen mempengaruhi variabel dependen secara signifikan.

\section{HASIL PENELITIAN DAN PEMBAHASAN}

\section{Permintaan Jasa Pariwisata}

Permintaan Jasa Pariwisata berbeda dengan permintaan barang. Karena jasa pariwisata tidak semua orang membutuhkannya, hanya orang- orang yang mempunyai kebutuhan untuk bersenang- senang yang akan menggunakan jasa pariwisata ini. Hal ini berbeda dengan permintaan pakaian, pakaian dibutuhkan oleh semua orang. Sehingga permintaan akan pakaian akan lebih banyak dibandingkan dengan permintaan jasa pariwisata. Untuk lebih jelas kondisi permintaan jasa pariwisata dari objek wisata pemandian air panas se-Kabupaten Garut yang dilihat dari data kunjungan wisatawan pada bulan April 2012 untuk lebih jelasnya dapat dilihat pada tabel 1.10

Tabel 1.10

\section{Data Permintaan Jasa Pariwisata Pada Bulan} April 2012

\begin{tabular}{ccc}
\hline No & Nama Objek Wisata & $\begin{array}{c}\text { Jumlah } \\
\text { Pengunjung }\end{array}$ \\
$\mathbf{1}$ & Antralina & 330 \\
$\mathbf{2}$ & Aquarius & 253 \\
$\mathbf{3}$ & Cipanas Indah & 391 \\
$\mathbf{4}$ & Danau Dariza & 622 \\
$\mathbf{5}$ & Darajat Pass & 118 \\
$\mathbf{6}$ & Lembur Kuring & 307 \\
$\mathbf{7}$ & Sabda Alam & 511 \\
$\mathbf{8}$ & Sumber Alam & 786 \\
$\mathbf{9}$ & Surya Alam & 315 \\
$\mathbf{1 0}$ & Tirtagangga & 580 \\
\hline
\end{tabular}

Sumber : Dinas Pariwisata Kabupaten Garut

\section{Hasil Analisis Instrumen Penelitian}

Uji R $\mathbf{R}^{\mathbf{2}}$ (Pengujian Koefisien Determinasi)

Dari hasil perhitungan dengan menggunakan bantuan Eviews ver 5.1 diperoleh nilai $\mathrm{R}$ dan $\mathrm{R}^{2}$ sebagai berikut :

Tabel 1.11 
Uji Koefisien Determinasi $\mathbf{R}^{2}$

\begin{tabular}{ccccc}
\hline Model & $\mathbf{R}^{\mathbf{2}}$ & $\mathbf{F}$ & $\begin{array}{c}\text { Probabili } \\
\text { ty }\end{array}$ & Sig \\
Regre & $\mathbf{0 . 4 8 1 6 2}$ & 37.8607 & 0.005 & 0,00 \\
si 2 & $\mathbf{3}$ & 2 & & 0 \\
\hline
\end{tabular}

Sumber : output Eviews

Berdasarkan hasil estimasi, diperoleh nilai koefisien determinasi $\left(\mathrm{R}^{2}\right)$ sebesar 0.4816 atau $48,16 \%$, artinya besarnya sumbangan (kontribusi) variabel bebas tarif/harga objek wisata $\left(\mathrm{X}_{1}\right)$ pendapatan $\left(\mathrm{X}_{2}\right)$, fasilitas $\left(\mathrm{X}_{3}\right)$, dan selera $\left(\mathrm{X}_{4}\right)$ terhadap variabel dependen permintaan jasa pariwisata pemandian air panas (Y) sebesar $48,16 \%$, dan sisanya sebesar $51,84 \%$ dipengaruhi oleh faktor lain diluar model.

\section{Analisis Regresi secara Simultan (Uji F)}

Untuk menguji pengaruh secara simultan variabel bebas $(\mathrm{X})$ terhadap variabel terikat $(\mathrm{Y})$ dilakukan dengan uji $F$, yaitu dengan membandingkan nilai $\mathrm{F}$ hitung yang diperoleh dari hasil uji data dengan menggunakan Eviews ver 5.1 dibandingkan dengan nilai $\mathrm{F}$ tabel, nilai $\mathrm{F}$ tabel diperoleh dengan melihat $\mathrm{F}$ tabel yang dapat diketahui dari melihat nilai v 1 dan nilai v 2 untuk dapat melihat nilai $\mathrm{v} 1$ dapat diketahui dengan menggunakan rumus $\mathrm{k}-1$, dimana ka adalah jumlah variabel dependen dan independen, kemudian untuk mencari $\mathrm{v} 2$ dapat diketahui dengan melihat nilai dari $\mathrm{n}-\mathrm{k}$, dimana $\mathrm{n}$ adalah jumlah responden dan $\mathrm{k}$ adalah jumlah variabel. Hasilnya dapat dilihat pada tabel 1.12:
Tabel 1.12

Uji Koefisien Regresi Simultan

\begin{tabular}{|c|c|}
\hline$F_{\text {hitung }}$ & \\
\hline 37.86072 & $>$ \\
\hline
\end{tabular}

Uji $F$ ini dugunakan untuk menguji variabel independen secara keseluruhan atau bersama-sama, untuk melihat apakah variabel independen secara keseluruhan mempengaruhi variabel dependen secara signifikan. Kriteria pengujian nilai $F$ adalah jika $F_{\text {hitung }}>\mathrm{F}_{\text {tabel }}$ dengan taraf keyakinan $95 \%$.

Dari hasil perhitungan regresi dengan menggunakan EViews ver 5.1 diperoleh nilai $F_{\text {hitung }}$ sebesar 37,86072 dan $\mathrm{F}_{\text {tabel }}$ sebesar 2,65 sehingga dapat disimpulkan bahwa $F_{\text {hitung }}>\mathrm{F}_{\text {tabel}}$, yang artinya bahwa secara simultan atau bersamasama variabel independen berpengaruh secara signifikan terhadap variable dependen permintaan jasa pariwisata pemandian air panas se Kabupaten Garut.

\section{Analisis Regresi secara Parsial (Uji t)}

Selain uji F perlu juga dilakukan uji t guna mengetahui tingkat signifikansi statistik dari pengaruh masing- masing variabel bebas terhadap variabel terikat.

Hasil regresi berganda dengan mrnggunakan EViews ver 5.1 dapat diketahui besarnya $\mathrm{t}$ hitung untuk masing- masing variabel bebas yaitu sebagai berikut :

Tabel 1.13

Uji Hipotesis Secara Parsial (Uji t)

\begin{tabular}{cccccc}
\hline Variabel & $\mathbf{t}_{\text {hitung }}$ & & $\mathbf{t}_{\text {tabel }}$ & Keputusan & Kesimpulan \\
$\mathbf{X 1}$ & -2.064292 & $>$ & $-1,658$ & Ho ditolak & Signifikan \\
$\mathbf{X 2}$ & 5.002936 & $>$ & 1,658 & Ho ditolak & Signifikan \\
$\mathbf{X 3}$ & 8.817469 & $>$ & 1,658 & Ho ditolak & Signifikan \\
$\mathbf{X} 4$ & 0.150744 & $<$ & 1,658 & Ho diterima & Tidak Signifikan \\
\hline
\end{tabular}

Dalam pengujian hipotesis melalui uji $t$ ini, penulis menggunakan tingkat kesalahan sebesar 5 $\%$ atau 0.05 pada taraf signifikansi $95 \%$ dengan df $=\mathrm{n}-\mathrm{k}-1(168-4-1)=163$. Adapun hasil uji $\mathrm{t}$ masing-masing variabel bebas (tarif/harga objek wisata, pendapatan konsumen, fasilitas wisata, dan selera) adalah sebagai berikut :

1. Uji t variabel $\mathrm{X}_{1}$ (Tarif/Harga Objek Wisata) 
Dari Tabel 4.22 hasil uji $t$ dengan menggunakan EViews ver 5.1 untuk koefisien $\mathrm{X}_{1}$ (tarif/harga objek wisata) diperoleh $t_{\text {hitung }}$ sebesar $-2,064292$ sedangkan $t_{\text {tabel }}$ dengan $\mathrm{df}=\mathrm{n}-\mathrm{k}-1=163$ dengan derajat kepercayaan $95 \%$ satu arah diperoleh nilai - 1,658, dan menunjukan bahwa $t_{\text {hitung }}>t_{\text {tabel }}$ atau $-2,064292>-1,658$ berada pada daerah penolakan Ho yang berarti bahwa hipotesis dalam penelitian ini $\mathrm{H}_{0}$ ditolak dan $\mathrm{H}_{\mathrm{a}}$ diterima dan berarti tarif/harga objek wisata berpengaruh negatif dan signifikan terhadap permintaan jasa pariwisata, hal ini juga dapat diketahui dengan melihat nilai probabilitasnya yaitu sebesar 0,0406 lebih kecil dari 0,05 .

2. Uji t variabel $X_{2}$ (Pendapatan Konsumen)

Dari Tabel 4.22, untuk koefisien $\mathrm{X}_{2}$ diperoleh nilai thitung 5,002936 dan tabel dengan derajat kepercayaan $95 \%$ diperoleh sebesar 1,658 Karena $t_{\text {hitung }}>\mathrm{t}_{\text {tabel }}, 5,002936>1,658$, maka $\mathrm{H}_{0}$ ditolak dan $\mathrm{H}_{\mathrm{a}}$ diterima. Yang berarti pendapatan konsumen berpengaruh positif dan signifikan terhadap permintaan jasa pariwisata, hal ini juga dapat diketahui juga dengan melihat nilai probabilitasnya yaitu sebesar 0,000 lebih kecil dari 0,05 .

\section{Uji t Variabel $X_{3}$ (Fasilitas Wisata)}

Dari Tabel 4.22, untuk koefisien $\mathrm{X}_{2}$ diperoleh nilai thitung 8,817469 dan $t_{\text {tabel }}$ dengan derajat kepercayaan $95 \%$ diperoleh sebesar 1,658 Karena $t_{\text {hitung }}>\mathrm{t}_{\text {tabel }}, 8,817469>1,658$, maka $\mathrm{H}_{0}$ ditolak dan $\mathrm{H}_{\mathrm{a}}$ diterima. Yang berarti fasilitas wisata berpengaruh positif dan signifikan terhadap permintaan jasa pariwisata sebesar, hal ini juga dapat diketahui juga dengan melihat nilai probabilitasnya yaitu sebesar 0,000 lebih kecil dari 0,05 .

\section{Uji t Variabel $\mathrm{X}_{4}$ (Selera Konsumen)}

Dari Tabel 4.22 hasil uji $t$ dengan menggunakan Eviews ver 5.1 untuk koefisien $\mathrm{X}_{4}$ (selera) diperoleh thitung sebesar 0,150744 sedangkan $t_{\text {tabel }}$ dengan derajat kepercayaan $95 \%$ diperoleh nilai 1,658 , dan menunjukan bahwa $t_{\text {hitung }}<t_{\text {tabel }}$ atau $0,150744<1,658$ berada pada daerah penerimaan $\mathrm{H}_{0}$ yang berarti bahwa hipotesis dalam penelitian ini $\mathrm{H}_{0}$ diterima dan $\mathrm{H}_{\mathrm{a}}$ ditolak hal itu menunjukan selera konsumen tidak berpengaruh terhadap permintaan jasa pariwisata hal ini juga dapat diketahui dengan melihat nilai probabilitasnya yaitu sebesar 0,8804 lebih besar dari 0,05 .

Dalam penelitian ini, fasilitas wisata yang diukur mengacu kepada standar kelayakan daerah tujuan wisata yang dikemukakan oleh Lothar A Kreck (Oka A Yoeti 2008:119) dengan kriteria ketersediaan objek, akses, akomodasi, fasilitas, transportasi, catering service, aktivitas rekreasi, pembelanjaan, kominikasi, sarana olahraga, ibadah dan pendidikan. Oleh karena itu, dirasa sangat penting peningkatan fasilitas wisata di daerah tujuan wisata.

Hal ini bisa dijadikan acuan oleh para pengelola usaha jasa pemandian air panas agar bisa memberi kepuasan para konsumen dengan cara memperbaiki dan melengkapi fasilitas yang tersedia di tempat pariwisata pemandian air panas yang diperlukan dalam suatu objek wisata pemandian air panas yang di butuhkan konsumen pada sarana dan prasarana objek wisata pemandian air panas yaitu :

Sarana :

1. Kolam rendam berair jernih

2. Kolam rendam bersih tidak berlumut

3. Kolam rendam beragam ukuran ada untuk dewasa dan anak-anak

4. Tersedia kolam rendam privacy

5. Terdapat permainan anak seperti perosotan,dll yang aman.

6. Kolam rendam berlantaikan keramik/marmer/kerikil yang layak dan terawat

7. Tersedia semprotan therapy air panas di sekitar kolam

Prasarana :

1. Tersedia tempat sampah yang mudah terlihat

2. Terdapat petugas keamanan di sekitar kolam seperti life guard

3. Terdapat tempat beribadah yang layak

4. Terdapat tempat penyewaan alat renang

5. Terdapat tempat pembelanjaan alat renang

6. Terdapat penyewaan loker yang aman

7. Terdapat kantin atau restoran

8. Terdapat sarana informasi dan komunikasi seperti televisi, signal $\mathrm{hp}$, akses internet maupun telephone umum 
9. Terdapat fasilitas perbankan seperti ATM

10. Tempat parkir yang luas, nyaman dan aman

11. Mudah dijangkau dengan kendaraan umum

Hubungannya dengan jenis dan mutu pelayanan sarana maupun prasarana wisata di daerah tujuan wisata dapat ditingkatkan dengan cara setiap daerah tujuan wisata menyesuaikan standar wisata yang baku dimana telah diatur baik secara nasional maupun internasional dalam hal ini pengelola wisata hanya tinggal memilih dan menetukan saja jenis dan kualitas yang akan disediakannya sesuai dengan apa yang menjadi kebutuhan wisatawan.

Selera konsumen tidak berpengaruh terhadap permintaan jasa pariwisata pemandian air panas. Artinya naik atau turunnya permintaan jasa pariwisata tidak dipengaruhi selera melainkan dipengaruhi oleh variabel diluar model penelitian. Selera masyarakat tidak dapat di ukur, bisa juga tergantung dengan musim. Responden di objek wisata pemandian air panas, lebih senang mengisi waktu luangnya dengan berdiam diri dirumah, dilihat dari hasil angket yang disebar yang sebagian besar diisi oleh pegawai swasta dan PNS, mereka cenderung mengisi seleranya dengan berdiam diri di rumah dari pada berkunjung ke tempat wisata setiap minggunya dikarenakan rutinitas hariannya yang padat. Selain itu selera konsumen bernilai subjektif Hasil ini bertolak belakang dengan teori, dikarenakan responden pemandian air panas Garut tidak terlalu mementingkan selera terhadap kunjungan ke tempat pemandian air panas tersebut, responden lebih melihat ke penghasilan yang dia punya dalam mengunjungi suatu tempat pariwisata.

Selera merupakan salah satu indikator yang mempengaruhi permintaan terhadap barang dan jasa. Apabila selera konsumen terhadap suatu barang atau jasa meningkat dimana harga barang dan jasa tetap maka akan cenderung untuk meningkatkan konsumsinya yang benar-benar sesuai dengan selera. Seperti yang dikemukakan

\section{REFERENSI}

[1] M. Lohmann, "New Demand Factors in Tourism *)," Eur. Tour. forum, 2004.
Sadono Sukirno (2005:82), menjelaskan bahwa selera atau cita rasa masyarakat memiliki pengaruh yang cukup besar terhadap keinginan masyarakat untuk membeli barang ataupun menggunakan jasa. Dalam melakukan permintaan terhadap suatu jasa, pilihan akhir konsumen sangat tergantung pada selera. Namun meskipun selera tidak berpengaruh dalam penelitian ini diharapkan pengelola usaha bisa menata dan menyediakan fasilitas sesuai dengan selera konsumen. Sesuai dengan yang dinyatakan oleh Vincent Gaspersz (2011:17) bahwa selera konsumen selalu berubah sepanjang waktu, dimana perubahannya dapat secara gradual atau secara cepat. Jadi pengelola wisata disarankan untuk melakukan perubahan seperti menambah fasilitas wahana atau merubah posisi fasilitas mengikuti perubahan selera konsumen tersebut.

\section{KESIMPULAN}

Tarif/harga berpengaruh negatif dan signifikan terhadap permintaan jasa pariwisata pemandian air panas. Artinya semakin tinggi tarif/harga objek wisata maka permintaan jasa pariwisata akan semakin rendah.

Pendapatan konsumen berpengaruh positif dan signifikan terhadap permintaan jasa pariwisata. Artinya semakin tinggi pendapatan konsumen maka permintaan jasa pariwisata akan semakin meningkat.

Fasilitas wisata berpengaruh positif dan signifikan terhadap permintaan jasa pariwisata. Artinya semakin lengkap fasilitas atau sarana dan prasarana wisata dalam suatu objek wisata maka permintaan jasa pariwisata akan semakin meningkat.

Selera tidak berpengaruh terhadap permintaan jasa pariwisata artinya naik atau turunnya permintaan jasa pariwisata pemandian tidak dipengaruhi oleh selera melainkan dipengaruhi oleh variabel lain di luar selera.

[2] Ani Triani. (2011) Analisis Faktor-faktor yang Mempengaruhi Permintaan Jasa 
Hotel. Bandung: Skripsi UPI. Tidak diterbitkan.

[3] Bilas, Richard A. (1995) Teori Mikro Ekonomi. Jakarta: Erlangga

[4] Buchari Alma. (2000) Manajemen Jasa dan Pemasaran Jasa. Alfabeta: Bandung

Bisnis.Alfabeta: Bandung

[6] DISBUDPAR Garut (2011) Panduan Wisata Garut.

[7] Fandy Tjiptono ( 2004) Manajemen Jasa. Yogyakarta. Andy Yogya

[8] Gamal Suwantoro. 2004. Dasar-dasar Pariwisata. Yogyakarta : ANDI

[9] Gujarati,Domador dan Zain S.(1978). Ekonometrika Dasar. Jakarta: Erlangga

[10] I Made Sukarsa (1999). Pengantar Pariwisata. Ujung Pandang: Dirjen Pendidikan tinggi Badan Kerjasama Perguruan Tinggi Negeri Indonesia Timur.

[11] Kotler, Philip (2002) Manajemen Pemasaran. Yogyakarta. Andy Yogya.

[12] Mankiw. (2000). Pengantar Ekonomi Jilid 1. Jakarta: Erlangga

[13] Nazir, M. (1999). Metode Penelitian (Edisi Keempat). Jakarta: Ghalia Indonesia.

[14] Nia Daniasih. (2005). Analisis Faktorfaktor yang Mempengaruhi Permintaan Jasa Hotel. Bandung: Skripsi UPI. Tidak diterbitkan.

[15] Nyoman S Pendit (1980) Ilmu Pariwisata Sebuah Pengantar Perdana. Jakarta: PT Pradnya Paramita

[16] Oka A Yoeti. (2006). Pengantar Ilmu Pariwisata. Bandung: Angkasa

[17] --------(2008). Ekonomi Pariwisata. Bandung: Angkasa

[18] (1996).

Pemasaran

Pariwisata. Bandung: Angkasa
[19] Pratama Rahardja, Mandala Manurung (2002) Teori Ekonomi Mikro Suatu Pengantar. Jakarata. FE UI

[20] R.G. Soekadijo (1997). Anatomi Pariwisata. Jakarta PT Gramedia Pustaka Utama

[21] Riduwan.(2003). Dasar-dasar Statistika. Bandung: Alfabeta

[22] Samuelson, Paul A. dan Nordhaus,W.D.( 2003). Ilmu Mikro Ekonomi. Jakarta :

[23] PT Media Global Edukasi

[24] Sadono Sukirno (2005) Pengantar Teori Mikro Ekonomi. Jakarta . PT Raja Grafindo Persada

[25] Sihite, Richard (2000). Tourism Industry. Surabaya: SIC

[26] Sugiyono (2008). Metode Penelitian Administrasi. Bandung: Alfabeta

[27] Suharsimi Arikunto (2010). Prosedur Penelitian Suatu Pendekatan Praktik. Jakarta: Rineka Cipta.

[28] Tedy Herlambang. (2002). Ekonomi Manajerial dan Strategi. Jakarta : PT. Raja Grafindo Persada

[29] Tim Penyusun Kamus Pembinaan dan Pengembangan Bahasa. (1999). Kamus Besar Bahasa Indonesia. Jakarta: Balai Pustaka

[30] Vegalianna Hadidjah (2008). Analisis Faktor-faktor yang Mempengaruhi Permintaan Jasa Pariwisata Kebun Binatang Bandung. Bandung: Skripsi UPI. Tidak diterbitkan.

[31] Vena Putri (2011). Analisis Faktor-faktor yang Mempengaruhi Permintaan Jasa Pariwisata. Bandung: Skripsi UPI. Tidak diterbitkan.

[32] Vincent Gaspersz (2011). Ekonomi Manajerial. Bogor: Vinchristo Publication.

[33] Yana Rohmana .(2010). Ekonometrika Teori dan Aplikasi dengan Eviews. 
Bandung : Laboratorium Pendidikan

Ekonomi dan Koperasi UPI. 